\title{
Erratum to: Independent directors, large shareholders and firm performance: the generational stage of family businesses and the socioemotional wealth approach
}

\author{
Rebeca García-Ramos ${ }^{1}$ - Belén Díaz-Díaz ${ }^{1}$. \\ Myriam García-Olalla ${ }^{1}$
}

Published online: 5 January 2016

(C) Springer-Verlag Berlin Heidelberg 2016

\section{Erratum to: Rev Manag Sci DOI 10.1007/s11846-015-0182-8}

After the publication of our paper in the Review of Managerial Science, Sven-Olof Yrjö Collin, Jenny Ahlberg and Yuliya Ponomareva brought to our attention the violation of citation standards and the improper recognition of their paper: Ahlberg and Ponomareva (2014). We sincerely apologize to the authors for this negligence in the literature review and conclusions citations.

This erratum aims to rectify the improper citation and to remedy the trouble caused to the authors, for which we are responsible.

In the Introduction section, paragraph 1 from line 1 to 2 fully resembles text in the paper written by Ahlberg and Ponomareva (2014), without quotes or proper acknowledgement.

In the Introduction section, paragraph 3 largely resembles text in the paper written by Ahlberg and Ponomareva (2014), and although it was cited, the whole paragraph should have been attributed to these authors.

In the Theoretical background section, paragraph 2 from line 9 to 11 fully resembles text in the paper written by Ahlberg and Ponomareva (2014), without quotes or proper acknowledgement.

In the Theoretical background section, paragraph 2 from line 11 to 14 largely resembles text in the paper written by Ahlberg and Ponomareva (2014), without proper acknowledgement.

The online version of the original article can be found under doi:10.1007/s11846-015-0182-8.

Rebeca García-Ramos

garciarr@unican.es

1 Department of Business Administration, University of Cantabria, Avenida de los Castros s/n, 39005 Santander, Spain 
In the Conclusion, limitations and future research section, paragraph 1 from line 3 to 6 largely resembles text in the paper written by Ahlberg and Ponomareva (2014), without proper acknowledgement, although it was cited on the same page.

In the Conclusion, limitations and future research section, paragraph 1 line 6 should have included the following: "In line with Ahlberg and Ponomareva (2014), we relax the central tenets...", because it largely resembles text in their paper.

In the Conclusion, limitations and future research section, paragraph 4 from line 1 to 13 and from line 15 to 17 largely resembles text in the paper written by Ahlberg and Ponomareva (2014), without proper acknowledgement.

Furthermore, the following references have to be corrected and added, respectively:

In the Theoretical background section, paragraph 1 line 6 , should refer to Zellweger et al. (2012) instead of Zellweger and Dehlen (2012).

In the subsection Data and sample under the section Research methodology, line 6, García-Ramos and García Olalla (2012) should have been referenced.

On the reference list, references Zellweger et al. (2012) and García-Ramos and García Olalla (2012) should be added.

\section{References}

Ahlberg J, Ponomareva Y (2014) "Bad Governance" of family firms: limitations of "good governance" discourse exemplified by governance practices of family firms. In: International conference "International competition in banking: theory and practice", Sumy, Ukraine, May 22, 2014

García-Ramos R, García Olalla M (2012) Corporate Governance, weak investor protection and financial performance in Southern Europe. Int J Bus Manag Stud 4(2):129-139

Zellweger T, Kellermanns F, Chrisman J, Chua J (2012) Family control and family firm valuation by family CEOs: the importance of intentions for transgenerational control. Organ Sci 23(3):851-868 